\title{
Sardinia 2009, XII International Waste Management and Landfill Symposium, S. Margherita di Pula, Sardinia, Italy
}

\author{
Roberto Valencia-Vazquez $\cdot$ Anne Farmer
}

Published online: 9 February 2010

(C) Springer Science+Business Media B.V. 2010

The Sardinia Symposia, established in 1987, have rapidly become the Reference Forum where leading experts meet and present their research activities and discuss new concepts and technologies. The Symposia have witnessed and contributed worldwide to the development of modern waste management strategies such as the integrated waste management hierarchy, the recovery of resources and energy and the sustainable landfilling of residues.

The twelfth edition of the Symposium held from 5-9 October 2009 included two general sessions, five specialized sessions and workshop sessions for a total of seven parallel tracks. Papers were selected according to quality by a group of International Referees from a total of more than 700 abstracts from 62 countries. Keynote issues for this edition included: waste policy and legislation, waste management strategies, waste characterisation and waste management in developing countries.

During the Symposium, interesting case studies and major controversial topics were discussed, thereby constituting an important opportunity for the exchange of knowledge and experiences. In

R. Valencia-Vazquez ( $\bowtie)$

Instituto Tecnologico de Durango, Blvd Felipe Pescador

1830 ote., Durango, Mexico

e-mail: r.valencia@unesco-ihe.org

\section{A. Farmer}

Eurowaste Srl, via Beato Pellegrino, 23, 35137 Padova, Italy particular, 24 workshops focusing on current hot topics such as Waste Minimization, Biological Production of Hydrogen and Sustainable Landfilling were organised. Workshops were opened by a short introductory presentation followed by discussion between experts in the field. The latter discussions represented the true 'core' of the symposia, where actual transfer of ideas, experiences and technology took place. Innovative topics such as Waste Electric and Electronic Equipment and Bioenergy Production were introduced.

In line with tradition, the symposium was preceded by IWWG training courses covering basic aspects on waste treatment, processes and management (Waste Management and Landfilling in Developing Countries, Landfill Processes \& Emissions, Landfill Design \& Barriers, Leachate Management, Landfill Gas Management, Leaching assessment using LeachXS and Composting), open to all participants and suited to beginners.

The Symposium was particularly intensive and lengthy, therefore the Organising Committee arranged a series of social activities that included concerts, an international soccer match, social dinners and a Gala Dinner. 